\title{
BMJ Open Conjoint analysis to understand preferences of patients with multiple sclerosis for disease-modifying therapy attributes in Spain: a cross-sectional observational study
}

\author{
Rafael Arroyo, ${ }^{1}$ Angel P Sempere, ${ }^{2}$ Elena Ruiz-Beato, ${ }^{3}$ Daniel Prefasi, ${ }^{4}$ \\ Agata Carreño, ${ }^{5}$ Montse Roset, ${ }^{5}$ Jorge Maurino ${ }^{4}$
}

To cite: Arroyo R, Sempere AP, Ruiz-Beato E, et al. Conjoint analysis to understand preferences of patients with multiple sclerosis for diseasemodifying therapy attributes in Spain: a cross-sectional observational study. BMJ Open 2017;7:e014433. doi:10.1136/bmjopen-2016014433

- Prepublication history for this paper is available online. To view these files please visit the journal online (http://dx.doi.org/10.1136/ bmjopen-2016-014433).

Received 27 September 2016 Revised 20 December 2016 Accepted 16 January 2017

CrossMark

For numbered affiliations see end of article.

Correspondence to Dr Jorge Maurino; jorge.maurino@roche.com

\section{ABSTRACT}

Objective: To assess patients' preferences for a range of disease-modifying therapy (DMT) attributes in multiple sclerosis (MS).

Design: A cross-sectional observational study.

Setting: The data reported were from 17 MS units throughout Spain.

Participants: Adult patients with relapsingremitting MS.

Main outcome: A conjoint analysis was applied to assess preferences. A total of 221 patients completed a survey with 10 hypothetical DMT profiles developed using an orthogonal design and rating preferences from 1 (most acceptable) to 10 (least acceptable). Medication attributes included preventing relapse, preventing disease progression, side effect risk, route and frequency of administration.

Results: Patients placed the greatest relative importance on the side effect risk domain (32.9\%), followed by route of administration ( $26.1 \%)$, frequency of administration $(22.7 \%)$, prevention of disease progression $(10.0 \%)$ and prevention of relapse (8.3\%). These results were independent of the Expanded Disability Status Scale score. The importance assigned to side effect risk was highest for patients with a recent diagnosis. Patients who had previously received more than one DMT gave a higher importance to relapse rate reduction than patients receiving their first DMT.

Conclusions: Patient DMT preferences were mainly driven by risk minimisation, route of administration and treatment schedule. The risk-benefit spectrum of available DMT for MS is becoming increasingly complicated. Understanding which treatment characteristics are meaningful to patients may help to tailor information for them and facilitate shared decision-making in clinical practice.

\section{INTRODUCTION}

Multiple sclerosis (MS) is a chronic inflammatory demyelinating disease of the central

\section{Strengths and limitations of this study}

- Little is known about the patients' preferences for different attributes of multiple sclerosis (MS) drug therapy.

- This study included a sample of 221 patients with relapsing-remitting MS managed in 17 different MS units at the national level, which allows results to be generalised to community practice. A comprehensive battery of the most important disease-modifying therapy attributes, including efficacy, tolerability, safety and convenience (route and frequency of administration), was analysed.

- The inclusion of a high percentage of patients with short disease duration is the main limitation of the study.

nervous system with genetic and environmental factors involved. ${ }^{1}$ Relapsing-remitting MS (RRMS) is the most common clinical form of MS. The first-generation of disease-modifying therapies (DMTs), $\beta$-interferons and glatiramer acetate, reduced the risk of relapses, were generally well tolerated and safe. ${ }^{2}$ Recently, an increasing number of new drugs have shown encouraging results for the management of RRMS due to higher efficacies compared with first-line DMTs. Consequently, major changes in the therapeutic management of RRMS are expected in coming years, which can impact on the natural progression of the disease. However, despite improved efficacy, these new agents have been associated with increased risk of serious adverse effects, thus altering the riskbenefit balance. ${ }^{2-4}$ The choice of new drugs should take into account aspects other than efficacy, including mechanisms of action, duration of effect, potential safety problems, 
convenience and patient preferences. ${ }^{5}$ In this context, therapeutic decisions are becoming increasingly complex.

In recent decades, there has been a big change in the physician-patient relationship. Patients and health authorities are increasingly demanding a more active role in decision-making processes related to medical care. This approach requires the patient to assess benefits and risks. Thus, in the management of MS, it is important to involve patients in the decision-making process regarding treatment initiation or switching due to the risk-benefit spectrum of the different DMTs available (partially effective and with significant side effect risk). ${ }^{6-8}$

In the real-world setting, patients evaluate a range of features to make decisions. The analysis of preferences can be used to further improve the knowledge of which treatment attributes are considered the most valuable by patients. ${ }^{9}$ There are different approaches for assessing patient preferences: methods using rating or choice designs to quantify preferences for various attributes of an intervention (conjoint analysis or stated-choice methods) or methods using direct elicitation of monetary values of an intervention (including contingent valuation or willingness-to-pay and willingness-to-accept methods).${ }^{10}$ Conjoint analysis is a multivariate technique in that the implicit values for an attribute of an intervention are derived from some overall score for a profile consisting of two or more attributes. Conjoint analysis has been conducted successfully to assess preferences for a diverse range of health interventions. ${ }^{10}$

The objective of this study was to assess the relative importance of a number of hypothetical DMT attributes for patients with RRMS.

\section{METHODS}

A multicentre observational cross-sectional study in adult patients with RRMS was conducted in 17 MS units throughout Spain (the EMPOWER study). The study was conducted between January and March 2016.

Patients were enrolled into the study who were aged 18 years or older with a diagnosis of RRMS (2010 McDonald criteria $^{11}$ ), an Expanded Disability Status Scale $^{12}$ (EDSS) score from 1 to 6 , and receiving a DMT for at least the past 3 months prior to inclusion. Written informed consent was obtained from all participants. Investigators included the first 12 consecutive patients who met the inclusion criteria for study participation. Competitive recruitment was established among centres. Study patients were treated by participating neurologists following current clinical practice and according to their judgement.

Conjoint analysis required the definition of hypothetical treatment options in terms of attributes (characteristics) and a subset of levels for each attribute. The DMT attributes and levels were developed through a review of current clinical trial literature and advanced clinical expertise. ${ }^{13}{ }^{14}$ A total of five attributes and two to four levels per attribute were defined to take into account the most important characteristics of all available DMTs: preventing relapse, preventing disease progression, side effect risk, route and frequency of administration (table 1). An orthogonal design was used to construct 10 cards containing unique combinations of all five attributes (table 2). Patients were asked to assess the level of each attribute combined to evaluate overall preference for each card relative to the other by first placing each card on a number line from 1 to 10 ( 1 being the best and 10 the worst possible selection).

Sociodemographic and clinical characteristics of the sample and patient-reported questionnaires were also collected. The EDSS was used to measure disability. Health-related quality of life (HRQoL) was assessed using the EuroQol five dimensions questionnaire (EQ-5D). ${ }^{15}$ The nine-item Shared Decision-Making Questionnaire (SDM-Q-9) ${ }^{16}$ is a patient-report tool for measuring patients' perceptions of how clinician performance fits the shared decision-making process. Total score ranges from 0 to 45 (the lowest to the highest extent of shared decision-making). Cognitive functioning was assessed using the Medical Outcomes Study Cognitive Functioning Scale (MOS Cog-R scale), ${ }^{17}$ a six-item self-report instrument that measures a range of day-to-day problems in several dimensions of cognitive functioning, including memory, attention/concentration and reasoning over the previous 4 weeks. Total scores range from 0 to 100 points, with higher scores indicating greater cognitive performance.

\begin{tabular}{|c|c|c|}
\hline Attributes & Levels & Description \\
\hline Preventing relapse & 2 & $\begin{array}{l}\text { Presenting a relapse every } \\
2 \text { years } \\
\text { Presenting a relapse every } \\
5 \text { years }\end{array}$ \\
\hline $\begin{array}{l}\text { Preventing } \\
\text { disease } \\
\text { progression }\end{array}$ & 2 & $\begin{array}{l}\text { Preventing the disease from } \\
\text { getting worse/progressing } \\
\text { for } 2 \text { years } \\
\text { Preventing the disease from } \\
\text { getting worse/progressing } \\
\text { for } 5 \text { years }\end{array}$ \\
\hline Side effect risk & 2 & $\begin{array}{l}\text { Rare but severe, } \\
\text { life-threatening side effects } \\
\text { (including PML) } \\
\text { Frequent but mild/moderate } \\
\text { side effects }\end{array}$ \\
\hline $\begin{array}{l}\text { Route of } \\
\text { administration }\end{array}$ & 3 & $\begin{array}{l}\text { Oral } \\
\text { Subcutaneous- } \\
\text { intramuscular } \\
\text { Intravenous }\end{array}$ \\
\hline $\begin{array}{l}\text { Frequency of } \\
\text { administration }\end{array}$ & 4 & $\begin{array}{l}\text { Daily } \\
\text { Every } 2 \text { days-weekly } \\
\text { Monthly } \\
\text { Twice per year }\end{array}$ \\
\hline
\end{tabular}




\begin{tabular}{|c|c|c|c|c|c|}
\hline Card & $\begin{array}{l}\text { Preventing } \\
\text { relapse }\end{array}$ & $\begin{array}{l}\text { Preventing disease } \\
\text { progression }\end{array}$ & Side effect risk & $\begin{array}{l}\text { Route of } \\
\text { administration }\end{array}$ & $\begin{array}{l}\text { Frequency of } \\
\text { administration }\end{array}$ \\
\hline A & $\begin{array}{l}\text { Presenting a } \\
\text { relapse every } \\
2 \text { years }\end{array}$ & $\begin{array}{l}\text { Preventing the disease } \\
\text { from getting worse/ } \\
\text { progressing for } 5 \text { years }\end{array}$ & $\begin{array}{l}\text { Rare but severe } \\
\text { life-threatening side effects } \\
\text { (including PML) }\end{array}$ & Oral & Daily \\
\hline$B$ & $\begin{array}{l}\text { Presenting a } \\
\text { relapse every } \\
2 \text { years }\end{array}$ & $\begin{array}{l}\text { Preventing the disease } \\
\text { from getting worse/ } \\
\text { progressing for } 2 \text { years }\end{array}$ & $\begin{array}{l}\text { Frequent but mild/ } \\
\text { moderate side effects }\end{array}$ & $\begin{array}{l}\text { Subcutaneous- } \\
\text { intramuscular }\end{array}$ & Daily \\
\hline C & $\begin{array}{l}\text { Presenting a } \\
\text { relapse every } \\
5 \text { years }\end{array}$ & $\begin{array}{l}\text { Preventing the disease } \\
\text { from getting worse/ } \\
\text { progressing for } 5 \text { years }\end{array}$ & $\begin{array}{l}\text { Rare but severe } \\
\text { life-threatening side effects } \\
\text { (including PML) }\end{array}$ & Intravenous & Daily \\
\hline $\mathrm{D}$ & $\begin{array}{l}\text { Presenting a } \\
\text { relapse every } \\
5 \text { years }\end{array}$ & $\begin{array}{l}\text { Preventing the disease } \\
\text { from getting worse/ } \\
\text { progressing for } 2 \text { years }\end{array}$ & $\begin{array}{l}\text { Frequent but mild/ } \\
\text { moderate side effects }\end{array}$ & Oral & $\begin{array}{l}\text { Every } 2 \text { days- } \\
\text { weekly }\end{array}$ \\
\hline$E$ & $\begin{array}{l}\text { Presenting a } \\
\text { relapse every } \\
2 \text { years }\end{array}$ & $\begin{array}{l}\text { Preventing the disease } \\
\text { from getting worse/ } \\
\text { progressing for } 5 \text { years }\end{array}$ & $\begin{array}{l}\text { Rare but severe } \\
\text { life-threatening side effects } \\
\text { (including PML) }\end{array}$ & $\begin{array}{l}\text { Subcutaneous- } \\
\text { intramuscular }\end{array}$ & $\begin{array}{l}\text { Every } 2 \text { days- } \\
\text { weekly }\end{array}$ \\
\hline $\mathrm{F}$ & $\begin{array}{l}\text { Presenting a } \\
\text { relapse every } \\
2 \text { years }\end{array}$ & $\begin{array}{l}\text { Preventing the disease } \\
\text { from getting worse/ } \\
\text { progressing for } 5 \text { years }\end{array}$ & $\begin{array}{l}\text { Rare but severe } \\
\text { life-threatening side effects } \\
\text { (including PML) }\end{array}$ & Oral & Monthly \\
\hline G & $\begin{array}{l}\text { Presenting a } \\
\text { relapse every } \\
5 \text { years }\end{array}$ & $\begin{array}{l}\text { Preventing the disease } \\
\text { from getting worse/ } \\
\text { progressing for } 2 \text { years }\end{array}$ & $\begin{array}{l}\text { Rare but severe } \\
\text { life-threatening side effects } \\
\text { (including PML) }\end{array}$ & $\begin{array}{l}\text { Subcutaneous- } \\
\text { intramuscular }\end{array}$ & Monthly \\
\hline $\mathrm{H}$ & $\begin{array}{l}\text { Presenting a } \\
\text { relapse every } \\
2 \text { years }\end{array}$ & $\begin{array}{l}\text { Preventing the disease } \\
\text { from getting worse/ } \\
\text { progressing for } 5 \text { years }\end{array}$ & $\begin{array}{l}\text { Frequent but mild/ } \\
\text { moderate side effects }\end{array}$ & Intravenous & Monthly \\
\hline I & $\begin{array}{l}\text { Presenting a } \\
\text { relapse every } \\
5 \text { years }\end{array}$ & $\begin{array}{l}\text { Preventing the disease } \\
\text { from getting worse/ } \\
\text { progressing for } 5 \text { years }\end{array}$ & $\begin{array}{l}\text { Frequent but mild/ } \\
\text { moderate side effects }\end{array}$ & $\begin{array}{l}\text { Subcutaneous- } \\
\text { intramuscular }\end{array}$ & Twice per year \\
\hline J & $\begin{array}{l}\text { Presenting a } \\
\text { relapse every } \\
2 \text { years }\end{array}$ & $\begin{array}{l}\text { Preventing the disease } \\
\text { from getting worse/ } \\
\text { progressing for } 2 \text { years }\end{array}$ & $\begin{array}{l}\text { Rare but severe } \\
\text { life-threatening side effects } \\
\text { (including PML) }\end{array}$ & Intravenous & Twice per year \\
\hline
\end{tabular}

\section{Statistical analysis}

Relative preferences were derived from rankings assigned by study patients to the 10 hypothetical scenarios, obtaining values ranging from 0 to 10 . Rankings had a hierarchical order that showed which cards were more or less preferred on an arbitrary scale. Patient preferences for hypothetical treatment were collected for the overall sample of valid patients and for stratified subgroups according to the EDSS score (1-3.0 and 3.5-6.0) with the aim to check that the preferences remain stable for different levels of disability. An ordinary least squares (OLS) regression model was used to estimate parameters, given that preferences were obtained in terms of ranges.

The model estimated by the OLS method, depending on the attributes and levels, is as follows:

$$
\mathrm{y}_{\mathrm{t}}=\alpha+\sum \beta_{\mathrm{ij}} \mathrm{x}_{\mathrm{ij}}+\mathrm{e}
$$

Where:

$\mathrm{y}_{\mathrm{t}}$ is the utility for a card $\mathrm{t}$;

$\alpha$ is the constant or intercept term;

$\beta_{\mathrm{ij}}$ is the utility or part-worth associated with the i-th attribute in the $\mathrm{j}$-th level; $\mathrm{x}^{\mathrm{ij}}=1$ when the $\mathrm{j}$-th level of the $\mathrm{i}$-th attribute is present in the card $\mathrm{t}$;

$\mathrm{x}_{\mathrm{ij}}=0$ when the $\mathrm{j}$-th level of the $\mathrm{i}$-th attribute is not present in the card t;

$\mathrm{e}$ is the error term.

The DMT preference card was the dependent variable and attributes used in the definition of the cards were independent variables. Relative (overall) and individual (at patient level) importance assigned to each attribute was derived by dividing the importance of a factor (maximum difference in utility values assigned to the levels) by the sum of all individual importance scores. The relationship between sociodemographic and clinical characteristics of patients, degree of patient disability, HRQoL, cognitive function and role in shared decisionmaking, and preference for treatment attributes were analysed using bivariate tests. A sensitivity analysis was performed which excluded those patients with inverse preferences (or investments) in efficacy and safety attributes.

Individual importance of each attribute (or level) for obtaining information about factors related to the importance assigned to different attributes was explored according to sociodemographic and clinical variables using bivariate tests. 


\section{RESULTS}

A total of 221 patients were included in the study. The mean age was $42.1 \pm 9.9$ years, and $68.3 \%$ were female. The mean EDSS score was 2.7 \pm 1.5 . Patients presented mean SDM-Q-9 and MOS Cog-R total scores of 38.7 \pm 8.5 and $41.5 \pm 11.1$, respectively. The most common current DMTs were first-line injectable therapies $(43.9 \%$ of patients), followed by fingolimod (19.0\%), dimethyl fumarate $(15.4 \%)$ and natalizumab $(12.2 \%)$. The main sociodemographic and clinical characteristics of the sample are presented in table 3 .

Table 4 describes estimated utilities reported by patients for attributes and levels assessed in hypothetical treatment scenarios. Patients had a higher preference for treatments with better efficacy (presenting a relapse every 5 years and/or preventing the disease from getting worse/progressing for 5 years), lower side effect risk (frequent but mild/moderate side effects), oral administration and lower frequency of administration (twice a year). Pearson's $\mathrm{R}$ and Kendall's $\tau$ coefficients, which provide measures of the correlation between observed and estimated preferences to assess the model's goodness of fit, showed high correlation coefficients $(0.998$ and 0.956 , respectively). Importance assigned to the different attributes show some differences according to the method used (average or relative importance). Considering the relative importance, the most important attribute for a DMT was tolerability/safety $(32.9 \%)$, followed by route of administration (26.1\%) and frequency of administration (22.7\%). Average importance, obtained at the patient level, was slightly different with schedule of administration being the most important attribute $(26.9 \%)$, followed by side effects $(26.8 \%)$ and route of administration (25.1\%). Estimated utilities reported by patients for attributes and levels were consistent in groups of patients stratified according to the EDSS score (1.0-3.0 and 3.5-6.0 strata; figure 1).

The sensitivity analysis performed, excluding those patients who showed individual reversed utilities in efficacy and safety attributes, put greater value in presenting a relapse in 5 years $(0.773$ vs 0.367$)$ and preventing the disease from getting worse or progressing for 5 years (0.764 vs 0.445$)$, but a minor preference for treatments administered twice per year $(0.727$ vs 1.137$)$.

Table 5 describes sociodemographic and clinical variables related to individual importance assigned to each DMT attribute. Patients having previously received more than one DMT gave a higher importance to relapse rate reduction than patients receiving their first DMT. The importance assigned to side effect risk was highest for those patients with a recent diagnosis of $<1$ year.

\section{DISCUSSION}

Treatment decisions in MS are becoming difficult after the introduction of several new DMTs with more complicated spectrums of risks and benefits. ${ }^{18}$ Involving patients with MS in the decision-making process is key to selecting the treatment that best suits the patient's profile and preferences. In our study, patients placed the greatest importance on the side effect risk domain with $32.9 \%$ relative importance, followed by route of administration $(26.1 \%)$, frequency of administration $(22.7 \%)$, prevention of disease progression $(10.0 \%)$ and prevention of relapse $(8.3 \%)$.

Several studies DMT preferences of patients with MS were recently published. ${ }^{12} 13$ 19-28 Such studies evaluated different spectrums of drug attributes. In a sample of 651 patients from the USA, a survey using five efficacy and safety drug attributes found that a delay in years to

\begin{tabular}{|c|c|c|c|c|}
\hline & $\begin{array}{l}\text { EDSS } 1.0-3.0 \\
(n=143)\end{array}$ & $\begin{array}{l}\text { EDSS } 3.5-6.0 \\
(n=78)\end{array}$ & $\begin{array}{l}\text { Total } \\
(n=221)\end{array}$ & p Value \\
\hline Age, mean (SD) & $40.0(9.8)$ & $46.0(8.9)$ & $42.1(9.9)$ & $<0.001$ \\
\hline Gender, female, n (\%) & $99(69.2 \%)$ & $52(66.7 \%)$ & $151(68.3 \%)$ & 0.763 \\
\hline \multicolumn{5}{|l|}{ Employment status, n (\%) } \\
\hline Employed (part-time or full-time) & $92(64.7 \%)$ & $15(29.5 \%)$ & $96(52.0 \%)$ & \multirow[t]{5}{*}{$<0.001$} \\
\hline Unemployed & $19(13.3 \%)$ & $9(11.5 \%)$ & $28(12.7 \%)$ & \\
\hline Retired due to RRMS & $10(7.0 \%)$ & $31(39.7 \%)$ & $41(18.6 \%)$ & \\
\hline Retired due to other reasons & $4(2.8 \%)$ & $2(2.6 \%)$ & $6(2.78 \%)$ & \\
\hline Without paid employment & $18(12.6 \%)$ & $13(16.7 \%)$ & $31(14.0 \%)$ & \\
\hline Some level of incapacity for work, $\mathrm{n}(\%)$ & $31(21.7 \%)$ & $44(66.5 \%)$ & $75(34.9 \%)$ & $<0.001$ \\
\hline Time of MS evolution (years), mean (SD) & $7.8(6.5)$ & $11.7(6.9)$ & $9.1(6.9)$ & $<0.001$ \\
\hline Time with DMT treatment (years), mean (SD) & $5.3(4.1)$ & $7.2(4.7)$ & $6.0(4.4)$ & 0.012 \\
\hline Time with current DMT treatment (years), mean (SD) & $3.5(3.7)$ & $3.4(3.3)$ & $3.5(3.5)$ & 0.529 \\
\hline Use of previous DMT treatment, $n(\%)$ & $75(52.4 \%)$ & $58(74.4 \%)$ & $133(60.2 \%)$ & $<0.001$ \\
\hline \multicolumn{5}{|l|}{ Presence of relapses, $\mathrm{n}(\%)$} \\
\hline Since diagnosis & $125(87.4 \%)$ & $76(97.4 \%)$ & $201(91.0 \%)$ & 0.013 \\
\hline During the past 2 years & $66(46.2 \%)$ & $34(43.6 \%)$ & $100(45.2 \%)$ & 0.714 \\
\hline During the past year & $32(22.4 \%)$ & $20(25.6 \%)$ & $52(23.5 \%)$ & 0.585 \\
\hline
\end{tabular}




\begin{tabular}{|c|c|c|c|}
\hline & Utility (SD) & $\begin{array}{l}\text { Importance } \\
\text { (relative) }\end{array}$ & $\begin{array}{l}\text { Importance } \\
\text { (averaged) }\end{array}$ \\
\hline \multicolumn{4}{|l|}{ Preventing relapse } \\
\hline Presenting a relapse every 2 years & $-0.367(0.131)$ & 8.3 & 10.4 \\
\hline Presenting a relapse every 5 years & $0.367(0.131)$ & & \\
\hline \multicolumn{4}{|l|}{ Preventing disease progression } \\
\hline $\begin{array}{l}\text { Preventing the disease from getting worse/progressing } \\
\text { for } 2 \text { years }\end{array}$ & $-0.445(0.131)$ & 10.0 & 11.1 \\
\hline $\begin{array}{l}\text { Preventing the disease from getting worse/progressing } \\
\text { for } 5 \text { years }\end{array}$ & $0.445(0.131)$ & & \\
\hline \multicolumn{4}{|l|}{ Side effect risk } \\
\hline Rare but severe, life-threatening side effects & $-1.457(0.131)$ & 32.9 & 26.5 \\
\hline Frequent but mild/moderate side effects & $1.457(0.131)$ & & \\
\hline \multicolumn{4}{|l|}{ Route of administration } \\
\hline Oral & $1.345(0.195)$ & 26.1 & 25.1 \\
\hline Subcutaneous-intramuscular & $-0.381(0.175)$ & & \\
\hline Intravenous & $-0.965(0.195)$ & & \\
\hline \multicolumn{4}{|l|}{ Frequency of administration } \\
\hline Daily & $-0.877(0.206)$ & 22.7 & 26.9 \\
\hline Every 2 days-weekly & $-0.527(0.251)$ & & \\
\hline Monthly & $0.267(0.206)$ & & \\
\hline \multirow[t]{2}{*}{ Twice per year (Constant) } & $1.137(0.251)$ & & \\
\hline & $5.875(0.133)$ & & \\
\hline
\end{tabular}

disability progression was the most important factor for treatment preferences. ${ }^{19}$ Risk of progressive multifocal leucoencephalopathy was the second most significant factor while the frequency of relapses had the least overall importance. Treatment frequency and route of administration showed a stronger influence on patient preferences compared with frequency of mild side effects in a German study. ${ }^{13}$ However, no efficacy attributes were assessed. Oral administration was preferred over injections by $93 \%$ of patients when treatment frequency and frequency of side effects were held constant. ${ }^{13}$ Poulos $e t a l^{20}{ }^{21}$ performed studies in the USA and Germany assessing several attributes of injectable treatments using a discrete-choice approach to derive utilities: number of years until MS symptoms get worse, number of relapses in the next 4 years, injection time, frequency of injections, influenza-like symptoms and infection-site reactions. Both studies identified the number of years until MS symptoms get worse as being the most important attribute, followed by influenza-like symptoms, frequency of injections per month and number of relapses in the following years. A study performed by Wilson et $a t^{22}$ used different attributes (prevent progression, prevent relapse, prevent changes on MRI, improve symptoms, common and severe side effects, treatment administration and time on market) and established a ranking (0-10) approach to derive utilities. Prevention of disease progression, relapses and changes on MRI were assessed on an annual basis, but taking into account a maximum prevention period of 5 years, the most important attribute was the presence of severe side effects, followed by administration routes. In addition, a study conducted in Canada, with a sample of 189 patients with RRMS as well as progressive MS using latent-class modelling, concluded that the most important attribute was the avoidance of serious adverse effects. $^{23}$

Our findings concur with those of Wilson et al using similar attributes to define scenarios and the same elicitation method. Prevention of relapse is not as relevant as preventing side effects. ${ }^{22}$ We identified main factors related to patient preferences for drug attributes, including previous experience with more than one DMT, number of relapses and HRQoL. Patients with prior DMT treatment gave higher importance to the impact of treatment on the prevention of relapse rate and lower importance to the side effects attribute. In a recent study performed to assess patient preferences for the full spectrum of DMT attributes, patients receiving their first DMT also gave higher importance to type, severity and duration of side effects. ${ }^{24}$ On the other hand, patients who had previously received multiple DMTs gave higher importance to the effect on relapse rate and its severity. The fact that patients with a longer disease duration tend to prioritise the efficacy profile of DMTs may be indicative of a better understanding of the disease, both from a theoretical and from a practical point of view. Wilson et $a l^{14}$ identified that treatment-naive patients had no significant relative preference for preventing disease progression, which could be associated with a lower disease activity. In addition, patients receiving the first-line DMTs such as $\beta$-interferons or glatiramer acetate displayed more aversion to fatal risk than those receiving the high-efficacy 


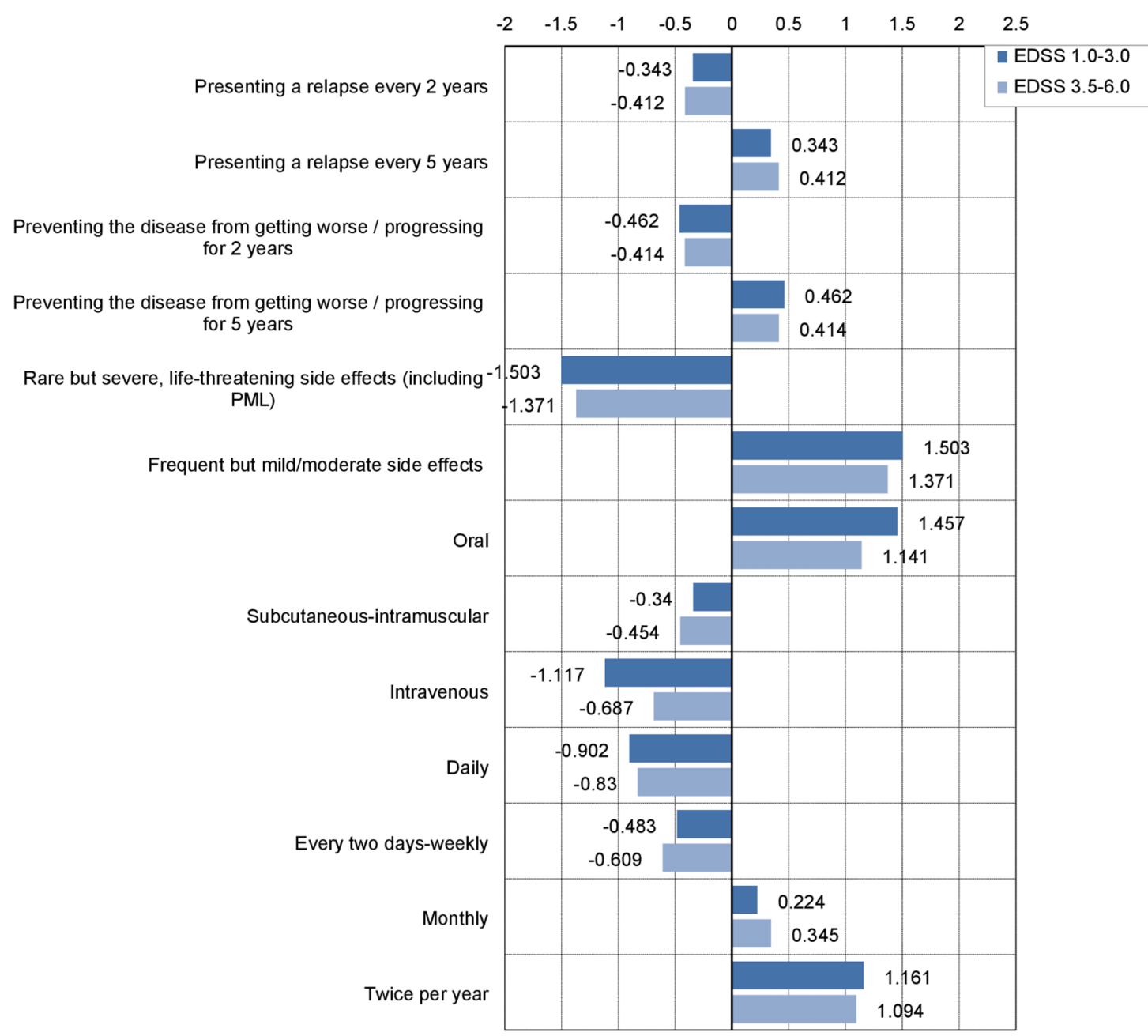

Figure 1 Utility scores for each level of the attribute according to the EDSS score. EDSS, Expanded Disability Status Scale.

DMTs fingolimod or natalizumab. The ability of natalizumab-treated patients to assume therapy-associated risks and the factors involved in such risk acceptance was assessed in a study published by Tur et $a l^{28}$ The authors defined risk acceptance as a multifactorial phenomenon which is partly explained by an adaptive process involving the perception of MS as a more severe disease. Therefore, it would be important to give special attention to patients newly diagnosed in efficacy aspects of available therapies.

Our study has several limitations. First, the sample population included a high percentage of patients receiving their first DMT (39.8\%). According to the study results, patients without prior treatment experience had a higher awareness about side effects, reducing the importance assigned to efficacy parameters. This high percentage of patients may explain the higher importance obtained for safety risk. Second, preference studies are classically limited in that the preference weights elicited are specific to the attributes and levels that are presented. It is possible that some attributes that are important to some patients were not included. In addition, the method used to derive utilities is a second study limitation as utility values and importance derived from conjoint analysis depend on attributes and levels used to define scenarios. Treatment efficacy was assessed in terms of prevention of relapses and disease progression, but not in terms of improving MS symptoms. Previous studies that included both attributes derived a higher importance for the MS symptoms attribute than for the number of relapses. ${ }^{20}{ }^{21}$ On the other hand, side effect risk was defined in terms of severe and lifethreatening adverse events, which could increase the importance assigned to this attribute. However, results obtained by Wilson et $a l^{22}$ using a similar definition for the side effects attribute are aligned with our study. In addition, it is important to consider the number of levels included in each attribute. A higher number of levels tend to be related to higher importance assigned to the attribute, given that a higher variability in response options tends to occur. Finally, another potential limitation is the absence of additional patient factors or characteristics that may impact preferences, such as personality traits. For example, a neurotic personality profile has previously been predicted to have a higher acceptance of natalizumab-associated risks. ${ }^{28}$ 
Table 5 Sociodemographic and clinical characteristics and individual importance assigned to each DMT attribute*

\begin{tabular}{|c|c|c|c|c|}
\hline $\begin{array}{l}\text { Sociodemographic or clinical } \\
\text { characteristics }\end{array}$ & $\begin{array}{l}\text { Preventing } \\
\text { relapse }\end{array}$ & $\begin{array}{l}\text { Preventing disease } \\
\text { progression }\end{array}$ & $\begin{array}{l}\text { Side } \\
\text { effect risk }\end{array}$ & $\begin{array}{l}\text { Route of } \\
\text { administration }\end{array}$ \\
\hline \multicolumn{5}{|l|}{ Previous DMT treatment } \\
\hline No & $9.0(10.5)$ & & & $21.8(13.2)$ \\
\hline Yes & $11.3(10.8)$ & & & $27.3(16.0)$ \\
\hline $\mathrm{p}$ Value & 0.027 & & & 0.008 \\
\hline \multicolumn{5}{|l|}{ Incapacity for work } \\
\hline Partial incapacity & & $12.1(7.5)$ & & \\
\hline Total incapacity & & $17.5(12.8)$ & & \\
\hline Absolute incapacity & & $11.8(7.9)$ & & \\
\hline Incapacity for severe disability & & $4.6(4.8)$ & & \\
\hline Not recognised & & $9.6(6.5)$ & & \\
\hline No incapacity & & $10.7(10.2)$ & & \\
\hline$p$ Value & & 0.048 & & \\
\hline \multicolumn{5}{|l|}{ Anxiety/depression (EQ-5D) } \\
\hline No & & $12.3(10.1)$ & & \\
\hline Yes & & $9.6(8.5)$ & & \\
\hline $\mathrm{p}$ Value & & 0.025 & & \\
\hline \multicolumn{5}{|c|}{ Longer time since MS diagnosis (years) } \\
\hline$<1$ & & & $39.0(14.4)$ & \\
\hline $1-2$ & & & $17.1(14.7)$ & \\
\hline $2-5$ & & & $24.0(16.0)$ & \\
\hline $5-10$ & & & $25.9(16.7)$ & \\
\hline $10-20$ & & & $30.3(15.7)$ & \\
\hline$>20$ & & & $21.8(15.7)$ & \\
\hline $\mathrm{p}$ Value & & & 0.001 & \\
\hline \multicolumn{5}{|c|}{ Greater number of relapses in the past 2 years } \\
\hline No relapses & & & $28.4(15.6)$ & $23.8(14.0)$ \\
\hline 1 relapse & & & $27.6(16.7)$ & $23.9(15.7)$ \\
\hline 2 or more relapses & & & $18.3(16.6)$ & $31.1(16.7)$ \\
\hline $\mathrm{p}$ Value & & & 0.005 & 0.030 \\
\hline
\end{tabular}

Despite these limitations, the study also has several strengths. The sample of 221 patients was managed in 17 different MS units at the national level, which allows results to be generalised to community practice. In addition, the sample size was large enough to allow the derivation of preference values according to the degree of disability (EDSS). Finally, a comprehensive battery of the most important DMT attributes, including efficacy, tolerability safety and convenience (route and frequency of administration), was analysed.

Patient preferences for DMT in our study were mainly driven by risk minimisation, route of administration and treatment schedule. There is no evidence that decisions based on patient preferences are better than those based on a drug's efficacy in order to achieve the best possible mid-long-term outcome for the patient. Nevertheless, understanding which DMT characteristics are meaningful to patients may help to tailor information and support decision-making in clinical practice.

Shared decision-making is a cornerstone of patientcentred care. A rating-based conjoint analysis is a feasible method for quantifying the relative preferences of patients with MS. Treatment decisions in MS should be made in collaboration between the neurologist and the patient, and they should be based on the best available evidence as well as on patient values and preferences. ${ }^{29} 30$

Author affiliations

${ }^{1}$ Department of Neurology, Hospital Universitario Quirónsalud, Madrid, Spain

${ }^{2}$ Department of Neurology, Hospital General Universitario de Alicante,

Alicante, Spain

${ }^{3}$ Health Economics and Outcomes Research Unit, Roche Farma SA, Madrid, Spain

${ }^{4}$ Medical Department, Roche Farma SA, Madrid, Spain

${ }^{5}$ Health Economics and Outcomes Research, IMS Health, Barcelona, Spain

Acknowledgements The authors acknowledge the other participating experts of the EMPOWER study. They also would like to express their gratitude to Cristina Garcia Bernaldez for leading the operational aspects of the study.

Contributors RA and JM developed the research question, designed the study and wrote the protocol. MR and AC performed the statistical analyses. All authors contributed to and have approved the final manuscript.

Funding The study was funded by Roche Farma SA, Spain.

Competing interests ER-B, DP and JM are employees of Roche Farma SA. $\mathrm{MR}$ and $\mathrm{AC}$ are employees of IMS Health.

Patient consent Obtained.

Ethics approval The study was approved by the Institutional Review Board of the Hospital Universitari Dr. Josep Trueta (Girona, Spain).

Provenance and peer review Not commissioned; externally peer reviewed. 
Data sharing statement No additional data are available.

Open Access This is an Open Access article distributed in accordance with the Creative Commons Attribution Non Commercial (CC BY-NC 4.0) license, which permits others to distribute, remix, adapt, build upon this work noncommercially, and license their derivative works on different terms, provided the original work is properly cited and the use is non-commercial. See: http:// creativecommons.org/licenses/by-nc/4.0/

\section{REFERENCES}

1. Compston A, Coles A. Multiple sclerosis. Lancet 2008;372:1502-17

2. Torkildsen $\varnothing$, Myhr KM, Bo L. Disease-modifying treatments for multiple sclerosis-a review of approved medications. Eur J Neurol 2016;23(Suppl 1):18-27.

3. Sempere AP, Gimenez-Martinez J. Safety considerations when choosing the appropriate treatment for patients with multiple sclerosis. Expert Op Drug Saf 2014;13:1287-9.

4. Wingerchuk DM, Weinsheker BG. Disease modifying therapies for relapsing multiple sclerosis. BMJ 2016;354:i3518.

5. Brück W, Gold R, Lund BT, et al. Therapeutic decisions in multiple sclerosis: moving beyond efficacy. JAMA Neurol 2013;70:1315-24.

6. Heesen C, Solari A, Giordano A, et al. Decisions on multiple sclerosis immunotherapy: new treatment complexities urge patient engagement. J Neurol Sci 2011;306:192-7.

7. Colligan E, Metzler A, Tiryaki E. Shared decision-making in multiple sclerosis: a review. Mult Scler 2017;23:185-90.

8. Bruce JM, Lynch SG. Multiple sclerosis: MS treatment adherencehow to keep patients on medication? Nat Rev Neurol 2011;7:421-2.

9. Ryan M, Scott DA, Reeves C, et al. Eliciting public preferences for healthcare: a systematic review of techniques. Health Technol Assess 2001:5:1-186.

10. Bridges JF, Huber AB, Marshall D, et al. Conjoint analysis applications in health: a checklist of the ISPOR good research practices for conjoint analysis task force. Value Health 2011;14:403-13.

11. Polman $\mathrm{CH}$, Reingold SC, Banwell B, et al. Diagnostic criteria for multiple sclerosis: 2010 revisions to the McDonald criteria. Ann Neurol 2011;69:292-302.

12. Kurtzke JF. Rating neurologic impairment in multiple sclerosis: an expanded disability status scale (EDSS). Neurology 1983;33:1444-52.

13. Utz JS, Hoog J, Wentrup A, et al. Patient preferences for disease-modifying drugs in multiple sclerosis therapy: a choice-based conjoint analysis. Ther Adv Neurol Disord 2014;7:263-75

14. Wilson L, Loucks A, Bui C, et al. Patient-centered decision making: use of conjoint analysis to determine risk-benefit trade-offs for preference sensitive treatment choices. J Neurol Sci 2014;344:80-7.
15. Badia X, Roset M, Monserrat S, et al. The Spanish version of EuroQoL: a description and its applications. Med Clin (Barcelona) 1999;112(Suppl 1):79-85.

16. De las Cuevas C, Perestelo-Perez L, Rivero-Santana A, et al. Validation of the Spanish version of the 9-item Shared Decision-Making Questionnaire. Health Expect 2015;18:2143-53.

17. Yarlas A, White MK, Bjorner JB. The development and validation of a revised version of the Medical Outcomes Study Cognitive Functioning Scale (Mos-Cog-R). Value Health 2013;16:334

18. $\mathrm{Ng} \mathrm{P}$, Murray S, Hayes SM. Clinical decision-making in multiple sclerosis: challenges reported internationally with emerging treatment complexity. Mult Scler Relat Disord 2015;4:320-8.

19. Johnson FR, Van Houtven G, Ozdemir S, et al. Multiple sclerosis patients' benefit-risk preferences: serious adverse events risks versus treatment efficacy. J Neurol 2009;256:554-62.

20. Poulos C, Kinter E, Yang JC, et al. Patient preferences for injectable treatments for multiple sclerosis in the United States: a discrete-choice experiment. Patient 2016;9:171-80.

21. Poulos C, Kinter E, Yang JC, et al. A discrete-choice experiment to determine patient preferences for injectable multiple sclerosis treatments in Germany. Ther Adv Neurol Disord 2016;9:95-104.

22. Wilson LS, Loucks A, Gipson G, et al. Patient preferences for attributes of multiple sclerosis disease-modifying therapies development and results of a ratings-based conjoint analysis. Int J MS Care 2015;17:74-82.

23. Lynd LD, Traboulsee A, Marra CA, et al. Quantitative analysis of multiple sclerosis patients' preferences for drug treatments: a best-worst scaling study. Ther Adv Neurol Disord 2016;9:287-96.

24. Kremer IE, Evers SM, Jongen PJ, et al. Preferences of patients with multiple sclerosis for attributes of disease modifying drugs: a nominal group technique and best-worst scaling. Value Health 2015;18:A761.

25. D'Amico E, Leone C, et al. Disability may influence patient willingness to participate in decision making on first-line therapy in multiple sclerosis. Funct Neurol 2016;31:21-3.

26. Visser LH, Heerings MA, Jongen PJ, et al. Perspectives and experiences of Dutch multiple sclerosis patients and multiple sclerosis-specialized neurologists on injectable disease-modifying treatment. Patient Prefer Adherence 2016;10:659-67.

27. Garcia-Dominguez JM, Muñoz D, Comellas M, et al. Patient preferences for treatment of multiple sclerosis with disease-modifying therapies: a discrete choice experiment. Patient Prefer Adherence 2016;10:1945-56.

28. Tur C, Tintoré M, Vidal-Jordana Á, et al. Risk acceptance in multiple sclerosis patients on natalizumab treatment. PLOS ONE 2013;8: e82796.

29. Gafson A, Craner MJ, Matthews PM. Personalised medicine for multiple sclerosis care. Mult Scler 2016. Published Online First 26 Sep 2016.

30. Fried TR. Shared decision making-finding the sweet spot. $N$ Engl J Med 2016;374:104-6. 